\title{
APPROACHING VERTICAL GREENERY AS PUBLIC ART: A REVIEW ON POTENTIALS IN URBAN MALAYSIA
}

\author{
Nur Izzah Abu Bakar*, Mazlina Mansor**, and Nor Zalina Harun** \\ *) Master candidate, Department of Landscape Architecture, Kulliyyah of Architec- \\ ture and Environmental Design (KAED), International Islamic University Malaysia \\ (IIUM), Kuala Lumpur, Malaysia. \\ **) Lecturer, Department of Landscape Architecture, KAED, IIUM, Malaysia. \\ e-mail: izzah1987@gmail.com
}

\begin{abstract}
When landscape becomes the work of art, it is becoming more significant to the community. However, finding practical and effective ways in which public art could present an environmental cause is yet to be fully explored. Therefore, one way to approach this issue is by increasing the Vertical Greenery technology's application, especially at the wall of building in the city. Vertical Greenery (VG) varies in term of definition, but all in all, it can be interpreted as the growing of plants in, up, or against the facade of a building. On the other hand, public art can be referred as an artwork that is located in public space, which welcomes public interactions. Thus, in order to further study the potential of VG implementation as public art, this paper reviews 25 selected real life projects in urban Malaysia as reference studies, which include Kuala Lumpur, Selangor Johor and Penang that applied VG in their development. It explored whether the VG's implemented is, for public art. Based on the study, the researcher found that VG is implemented for its environmental, economic and aesthetic value. The researcher also noted that all VG that has been implemented at the developments in some ways portray the basic idea of public art which is an artistic expression that is positioned in a freely accessed public space for the public to use, but not just any art placed outside yet still carries the basic concept of art, which to beautify spaces. Hence, the result had shown significant potentials for VG to be introduced as a new form of sustainable public art in urban Malaysia.
\end{abstract}

Keywords: Aesthetic value, environmental value, potentials, public art, Vertical Greenery (VG).

\section{ABSTRAK}

Ketika lanskap menjadi karya seni, hal ini menjadi lebih signifikan bagi masyarakat. Namun, menemukan cara-cara praktis dan efektif dimana seni publik bisa menghadirkan penyebab lingkungan belum sepenuhnya dieksplorasi. Oleh karena itu, salah satu cara untuk mendekati masalah ini adalah dengan meningkatkan ap- 
likasi teknologi Vertical Greenery, terutama pada dinding bangunan di kota. Vertical Greenery $(V G)$ bervariasi dalam hal definisi, tetapi secara keseluruhan,itu dapat diartikan sebagai tumbuhnya tanaman di, atas, atau terhadap fasad bangunan. Di sisi lain, seni publik dapat disebut sebagai sebuah karya seni yang terletak di ruang publik, yang menyambut interaksi publik. Dengan demikian, untuk lebih mempelajari potensi penerapan VG sebagai seni publik, penelitian ini mengulas 25 proyek nyata pilihan di perkotaan Malaysia sebagai studi referensi, yang meliputi Kuala Lumpur, Selangor Johor dan Penang yang menerapkan VG dalam perkembangan mereka. Ini meneliti apakah VG yang diterapkan adalah untuk seni publik. Berdasarkan studi tersebut, peneliti menemukan bahwa VG diimplementasikan untuk nilai lingkungan, ekonomi dan estetika. Peneliti juga mencatat bahwa semua VG yang telah dilaksanakan pada perkembangan dalam beberapa hal menggambarkan ide dasar dari seni publik yang merupakan ekspresi seni yang diposisikan di ruang publik yang dapat secara bebas diakses oleh publik untuk digunakan, tetapi tidak hanya seni apapun yang ditempatkan luar namun masih mengusung konsep dasar seni, yaitu untuk mempercantik ruang. Oleh karena itu, hasilnya menunjukkan potensi signifikan bagi VG untuk diperkenalkan sebagai bentuk baru dari seni publik yang berkelanjutan di perkotaan Malaysia.

Kata kunci: nilai estetika, nilai lingkungan, potensial, seni publik, Vertical Green$\operatorname{ery}(V G)$

\section{INTRODUCTION}

Art is usually associated with privatization. The audience is commonly from the elite groups, and it is normally placed in a gallery. On the other hand, public art, according to Bach (2001), is an artistic expression that is positioned in a freely accessed public space for the public to use and for everyone to enjoy. Nevertheless, Bostwick (2008) mentioned that artists and arts advocates are consistently trying to make a case for the arts by addressing economic and social aspects. Nonetheless, she then argued whether the artist also tackled the environmental aspects of public art. She asserted that there are a few studies conducted to explore the ways in which public art could provide an environmental purpose. Thus, one way to engage public art in environmental aspect is by increasing the Vertical Greenery (VG) technology applications on the walls of our buildings whereby a plain wall can be turned into a luscious plant-filled art vision. VG can become a work of art that is alive. For example, growing and choosing plants over the typical granite or marble finish allows one to make a strong green statement, in other word means 'greener art' (G TOWERRebuilding the green concept 2012).

Thus, in order to further study the potential of VG implementation as public art, this paper reviews 25 selected real life projects in urban Malaysia as reference studies which include Kuala Lumpur, Selangor and Johor that have applied VG in their development. It explores the current practice of VG in buildings development in urban Malaysia; identify the purpose and objective of the VG application in the building development and determine whether VG has the potential to become a new 
form of public art. Thus, this exploratory study is hoped to help architects, landscape architects or promoters of VG technology in further understanding the benefits of VG so that later, encourage wide and rapid implementation of VG in our urban developments in Malaysia.

\section{Public Art: An Overview}

The term 'public art' is subject to a variety of interpretations. It is relevant to everything from subway graffiti to government-funded monumental sculpture. It has been employed as a touchstone to describe any art that is not housed in formal museums or galleries. Public art, says painter-educator Jolly Koh (see Shunmugam, 2010) is any work of ornamentation or art that is in public places such as parks and street corners, and on buildings.

Hunting (2005) explained that public art exists in a matrix defined by two important functions; in terms of the physical space that it occupies and secondly in terms of the origin of its existence, simplified in three-by-three grid format (Table $1)$.

Table 1. Definition of Public Art by its Placement and Origin (Hunting 2005)

\begin{tabular}{|c|c|c|c|}
\hline & Private Placement & Partial Placement & Public Placement \\
\hline $\begin{array}{c}\text { Private } \\
\text { Origin }\end{array}$ & $\begin{array}{l}\text { Art purchased by individ- } \\
\text { uals or corporations and } \\
\text { placed in-side office } \\
\text { buildings, etc. }\end{array}$ & $\begin{array}{l}\text { 'Corporate art' dis- } \\
\text { played outside or in } \\
\text { common areas such } \\
\text { as shopping malls. }\end{array}$ & $\begin{array}{l}\text { Privately funded art } \\
\text { that has been donat- } \\
\text { ed to the city and } \\
\text { displayed in a park. }\end{array}$ \\
\hline $\begin{array}{l}\text { Partial } \\
\text { Public } \\
\text { Origin }\end{array}$ & $\begin{array}{l}\text { Works sponsored by non- } \\
\text { profit and charitable or- } \\
\text { ganizations on private } \\
\text { property. }\end{array}$ & $\begin{array}{l}\text { Small memorials in } \\
\text { street medians and } \\
\text { low-traffic areas. }\end{array}$ & $\begin{array}{l}\text { Public/private part- } \\
\text { nerships at athletic } \\
\text { venues, etc. }\end{array}$ \\
\hline $\begin{array}{l}\text { Fully Pub- } \\
\text { lic Origin }\end{array}$ & $\begin{array}{l}\text { Government funded art- } \\
\text { work placed in govern- } \\
\text { ment offices not generally } \\
\text { accessible to the public. }\end{array}$ & $\begin{array}{l}\text { Government funded } \\
\text { artwork placed in- } \\
\text { side libraries or } \\
\text { neighborhood parks. }\end{array}$ & $\begin{array}{l}\text { Full government } \\
\text { funding and promi- } \\
\text { nent, highly visible } \\
\text { locations }\end{array}$ \\
\hline
\end{tabular}

Source: Hunting 2005

Note: Public art is defined by its placement and origin for easy understanding

All in all, the operational definition of public art used in this paper is an artistic expression that is positioned in a freely accessed public space for the public to use, but not simply any art placed outside yet still carries the basic notion of art which is to beautify spaces.

Based on the studies done, there are various types of public art found. However, this study differentiates the types based on explanation by The Hamilton Public Art Master Plan (2009) which are summarized into Table 2. 
Table 2. Different Types of Public Art

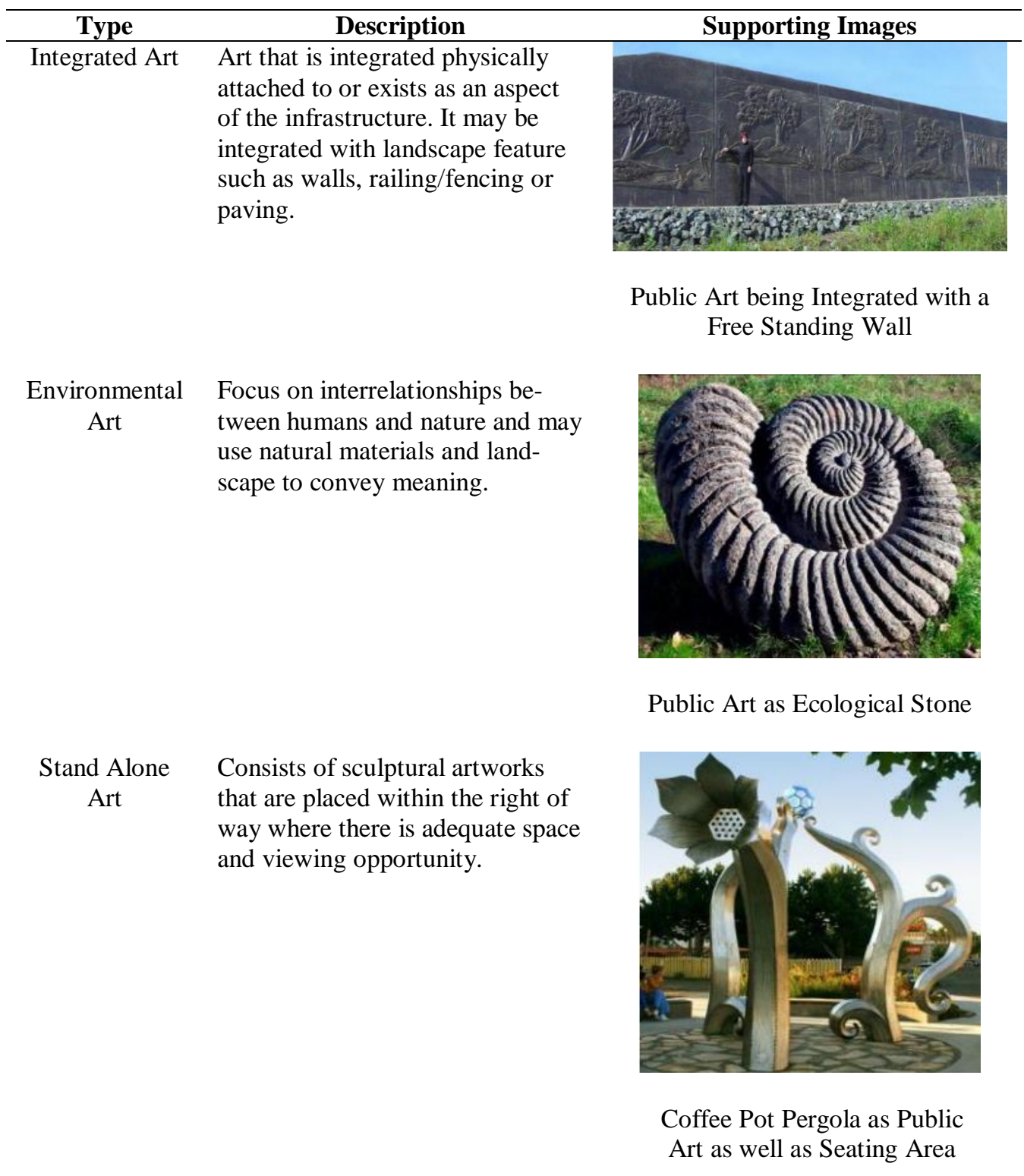

Note: Different types of public art and supporting images for further understanding

Public art plays brings benefits to both the community and the environment. Among the roles and value of public art are; aesthetical value, promoting the sense of community, celebrating the sense of place, addressing community needs, social implication and educational value. This view is also supported by Mustafa (2009) and many other authors claimed that public art also contributes to the environment in terms of place making and publicity, promotes a clear sense of community pride and identity, reflects cultural heritage, improves and enhances the built environment, 
contributes to a safer community, enhances tourism and economic growth as well as promotes community engagement and collaboration in public development.

\section{Public Art in Malaysian Context}

Public art has an important role to play in transforming the public sphere and contributing to the urban renaissance. Public art does not belong exclusively to the gallery and it can be an effective way of changing the way people think about their environment. Thus, in order for the art to benefits people, it means that our public art should be brought outside and be appreciated by the public. However, in Malaysian context, the situation differs from the way it should be. In a study by Mohd Fabian et. al. (2012), they reported that the understanding of public art among the community and related professions in Malaysia is still low. Among the issues that contributed to this problem are insufficient art educations, placement of the public art, low art quality, lack of community's participation and collaboration, as well as inadequate pertinent memories and identity in the public art. Piyadasa (see Shunmugam, 2010), asserted that public art should not be any construction just to fill and decorate a space but something that gives the country a sense of pride; a well thought art. Referring to Mustafa (2009), to help understand the ways in which public art practices in Malaysia, two main communication systems; authoritarian and paternalistic are highlighted. Authoritarian refers to a system of communication whereby a ruling group controls the society of the ruled (Williams see Muhizam Mustafa 2009). This method defines what is happening today in Malaysia whereby public art was installed by the administration without consulting the public despite the artworks were placed in the public realm. In contrast, the paternalistic mode of communication is an authoritarian form of communication with a conscience; it claims to have the benefit of the society in mind. Thus, it can be concluded that the government with the help of art experts, can provide such informative and experiences to its people in order for the public to benefit from the presence of great art in their surrounding.

\section{Vertical Greenery: An Overview}

The idea of having plants on the wall was not a new idea whereas the most famous VG systems in ancient history would most likely belong to the Hanging Gardens of Babylon. However, the modern version was initiated by Stanley Hart White, a Professor of Landscape Architecture. VG became popular after only in the 1980s, when Dr. Patrick Blanc, a French botanist and researcher, popularized the theory and approach to grow vertical gardens (Sia 2011). Additionally in Europe, during the 1980s, a growing interest in environmental issues conceived the hope of bringing nature into cities. However, in explaining why the green initiatives are only recently seen an upsurge, Daniels (2008) noted that it is because city leaders are recognizing that a cleaner environment is needed both to provide residents with good quality of life and to compete in the global economy.

Vertical greenery is a broad term referring to any ways in which plants can be grown on, up, or against the wall of a building such as a vine, as part of a window 
shade, as a balcony garden, or in a vertical hydroponic system. Various definitions vertical greenery can be concluded in Table 3.

Table 3. Different Definitions of Vertical Greenery (Badrulzaman et al. 2011) Bass and Baskaran (2003) and Peck et al. (1999)

\begin{tabular}{l} 
Terminology \\
\hline Vertical Garden/Wall \\
- Refer to all forms of plant surface of the \\
wall; used to determine the growing \\
plants, up, or on the façade of buildings.
\end{tabular}

Green Façade

- Climbing plants or cascading groundcover trained to cover specially designed supporting structures. Rooted at the base of these structures, in the ground, in intermediate planters or even on rooftops, the plants typically take 3-5 years to achieve full coverage.

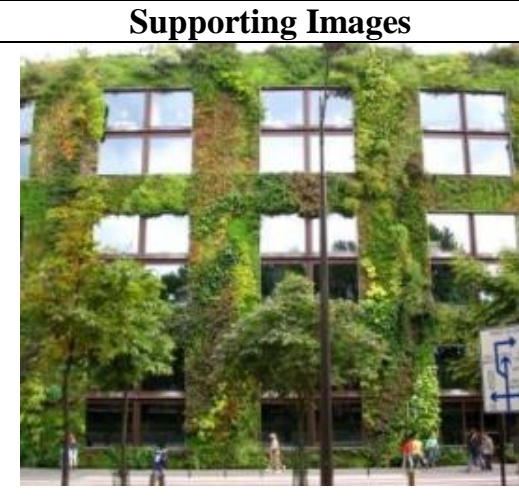

Vertical Wall on Jean Nouvel's Musée du quai Branly Source: Hart, K. (2001)

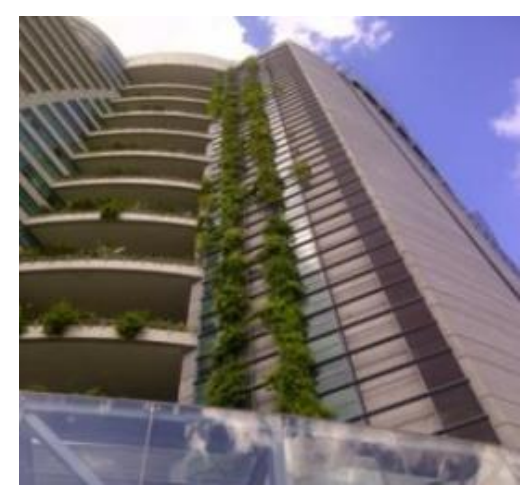

Green Façade at First Avenue, Bandar Utama Source: field survey (2013) 
Table 3. Continue

\begin{tabular}{l} 
Terminology \\
\hline Green Wall \\
- All forms of vegetation surface. This tech- \\
nology can be divided into two main cate- \\
gories; green facades and living walls.
\end{tabular}

Living Wall

- Consists of pre-vegetated panels, vertical modules or planted blankets that are fixed vertically to a structural wall or structure. These panels can be made of plastic, expanded polystyrene, synthetic fabric, clay, metal, and concrete.

\section{Green Space Wall}

- An ecosphere that doubles as an exterior wall or mixed interior/exterior spaces in new development. These walls can create multiple, synergistic uses of space.

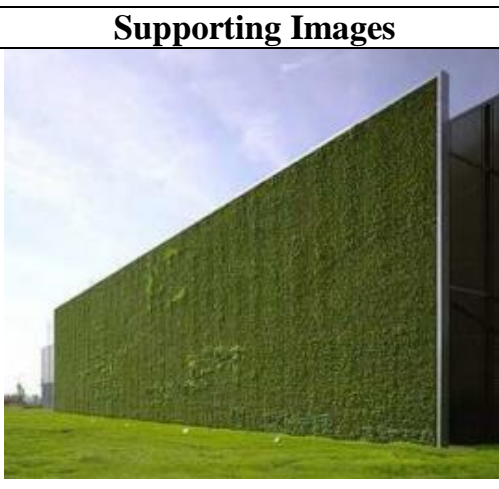

Citi Data Center in Frankfurt Features a Green Wall Featuring Plants that are Irrigated with Recycled Water.

Source: http://www.datacenterknowledge com/leed-platinum-data-centers/

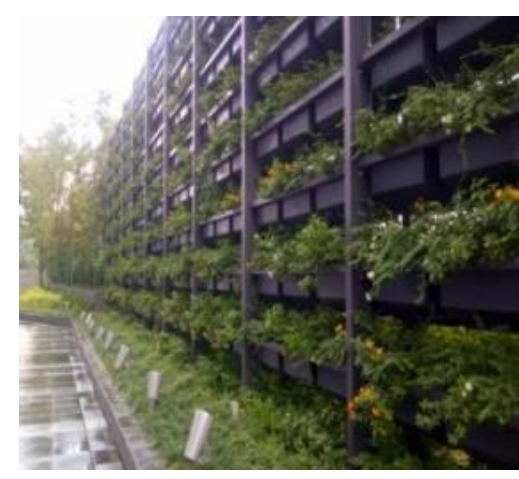

Living Wall in front of Intermark Building's Porte Cochere Source: field survey (2013)

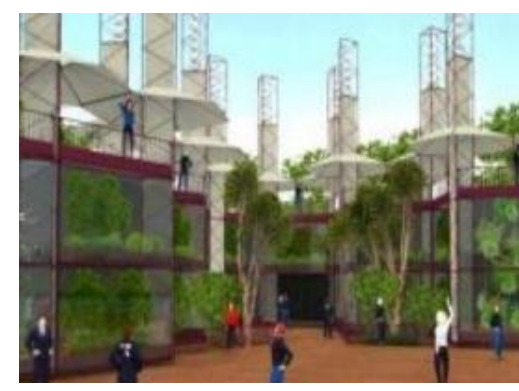

Example of New Building using a

Green Space Wall Source: Birkeland (2008) 
Table 3. Continue

\begin{tabular}{l} 
Terminology \\
\hline Green Scaffolding \\
- Applies mainly to eco-retrofitting, essen- \\
tially wraps a light weight structure around \\
the exterior of existing buildings to pro- \\
vide the full range of climatic and ecosys- \\
tem functions.
\end{tabular}

Biofacade Wall

- Referred to vegetation which was guided to climb up through the structure like wires or cables.

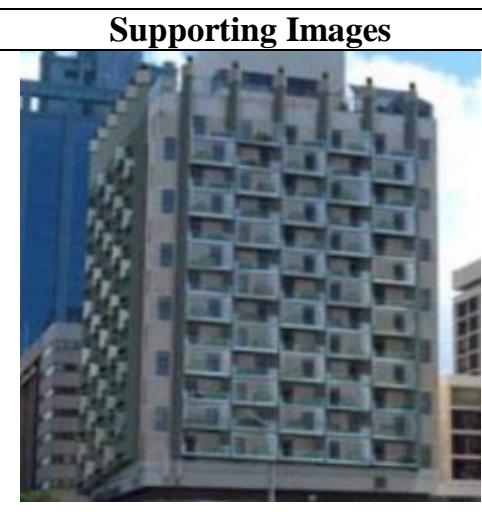

Example of Eco-Retrofit using Green Scaffolding Source: Birkeland (2008)

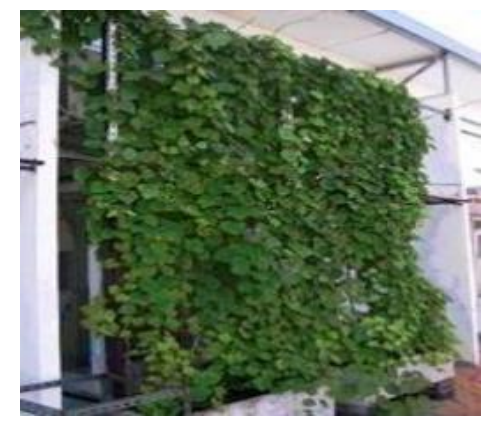

Biofacade Wall with Ivy Plant Installation

Source: Pasinee Sunakorn, Chanikarn Yimprayoon (2011)

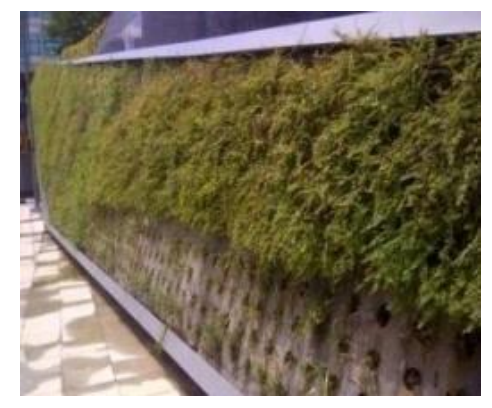

Vertical Greenery System (Hydroponic System) at Platinum Sentral

Source: field survey (2013) 
The benefits of infusing a city with greenery varied but the most obvious benefit would be visual. It would create an appealing atmosphere that provides relief from the congested urban surroundings. The second advantage is environmental. This is because plants improve air quality, absorb storm water and slow the formation of ground level-ozone (Bonham and Smith, 2008). Thus, VG is seen as one form to introduce more green to the city. It helps to improve the overall environmental quality and serves as a solution to increase our connection with nature. Table 4 categorized benefits of vertical greenery into three categories, namely aesthetic, environment and economic.

Table 4. Different Benefits of VG

\begin{tabular}{l} 
Category \\
\hline Aesthetic \\
1. Greener skyline and visual relief from ur- \\
ban environment \\
2. Enhance architectural designs, create ico- \\
nic landmarks \\
3. Screen and isolate views \\
4. Enhancing public spaces \\
5. Limiting the negative psychological effect \\
associated with property demarcation.
\end{tabular}

Economic

1. Reduction of cooling loads through better insulation and shading

2. Improving acoustic insulation

3. Increasing property values

4. Protection of building facade

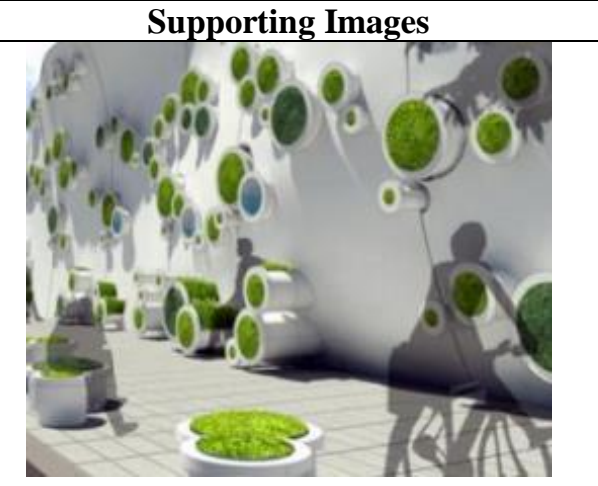

Symbiotic Green Wall to Improve Conventional Construction Wall Source: inhabitat.com (2009)

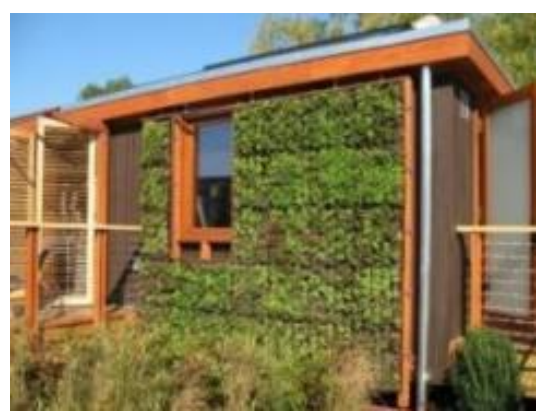

Lush Walls Create a Positive Perception for Prospective Property Purchasers Source: interface (2013) 
Table 4. Continue

\begin{tabular}{l}
\multicolumn{1}{c}{ Category } \\
Environment \\
1. Reduction of the UHI effect and regulation \\
of the microclimate \\
2. Improving the air quality \\
3. Enhancement of biodiversity by adding \\
natural habitats in the city \\
4. Improving rain water retention and onsite \\
$\quad$ wastewater treatment \\
5. Therapeutic effects of plants and landscape \\
6. Sound Insulator \\
7. Improved Energy Efficiency \\
8. Building Structure Protection \\
\hline
\end{tabular}

Note: Various definitions of Vertical Greenery and its supporting images

VG is characterised by its system in which it is constructed on site. A considerable amount of literature has been published on VG system. The two main types of VG are modular trellis/carrier systems and cable and rope wire/support sys tems (Figure 1). The carrier system which consist of rigid lightweight panels, are installed vertically as either wall-mounted or freestanding systems. It is designed in such a way to hold the planting media vertically. They can be used on tall buildings in conjunction with intermediate planters or on rooftops. These planters may be required where the growth of climbing plants is physically restricted. They are able to support bigger selection of plants, for instance shrubs, ferns, groundcovers, grasses, sedges and even mosses.

Conversely, cable and rope wire/support system (Figure 2) contains a kit of parts that includes wire trellises, high-tensile anchors, steel cables, spacers, and supplementary equipment. It helps to guide plants up on the vertical surface. Vertical and horizontal wires can be attached through cross clamps to create a flexible trellis system in various sizes and patterns. Other than that, stainless steel wire-rope nets can be supported on flexible or rigid frames to cover large areas. It allows cascading groundcovers as well as climbing plants to grow up the façade on specially designed support structures. However, apart from these two systems, Skyrise Greenery (2012) added another method which is the planter system (Figure 3). The planter system consists of planter boxes mounted at regular intervals onto a structure or frame. Stacked on top on another, they create extensive green wall coverage. Nevertheless, the system is similar to carrier system in terms of its ability to support a greater diversity of plants as compared to support systems. 


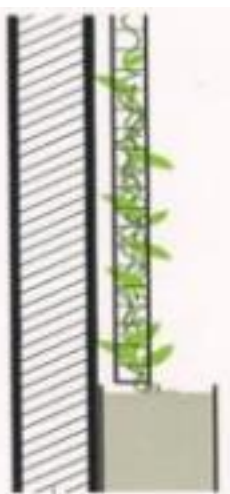

Figure 1.

Carrier System

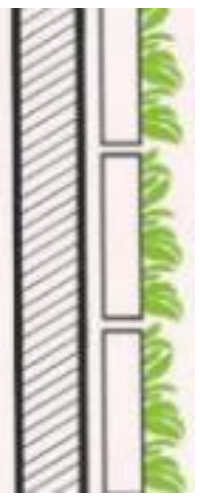

Figure 2.

Support System Source: Author

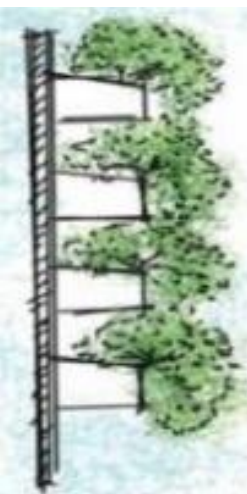

Figure 3.

Planter System

In terms of application, VG has been actively applied in various countries such as France, Great Britain, USA, Japan and Singapore. Example of the VG's implementation methods is shown in Table 5.

Table 5. Various Implementation of VG Around the World

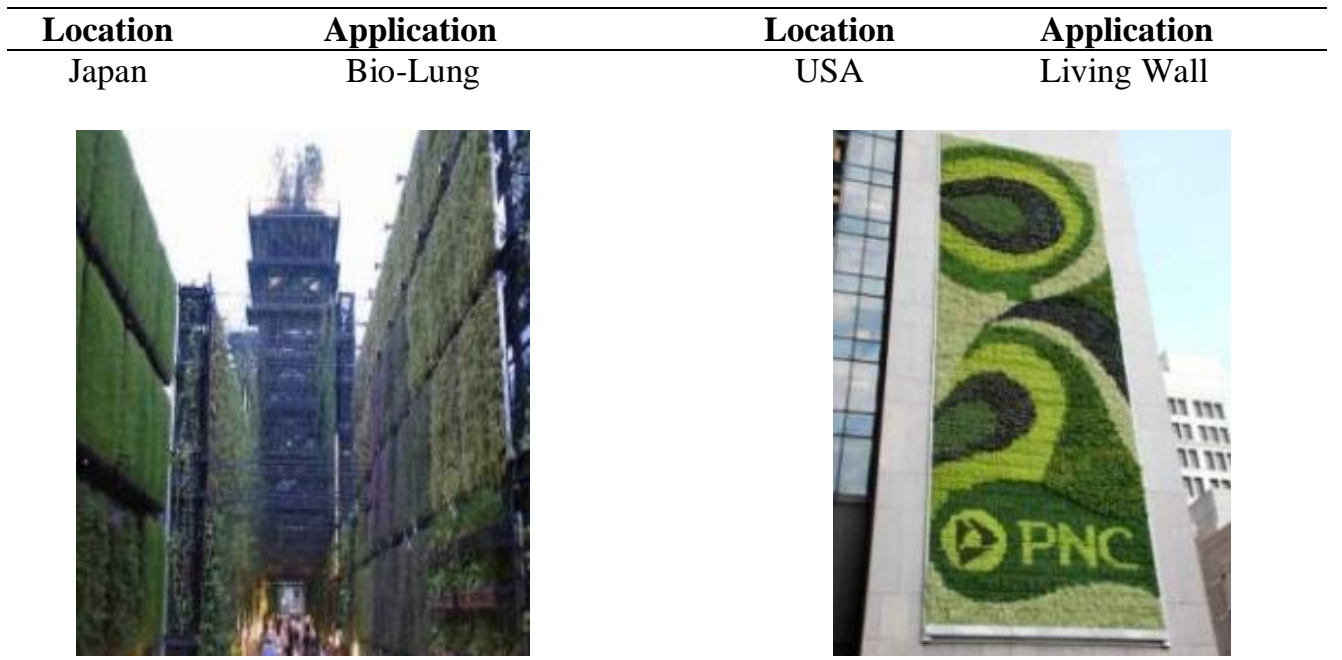

Japan's Bio-Lung constructed for Japan's Aichi Expo in 2005 Source: Living Walls: 15 More Vertically Vegetated Buildings (n.d.)
PNC Living wall with logo as a bold commitment statement from PNC towards the environment Source: Meinhold (2009) 
Table 5. Continue
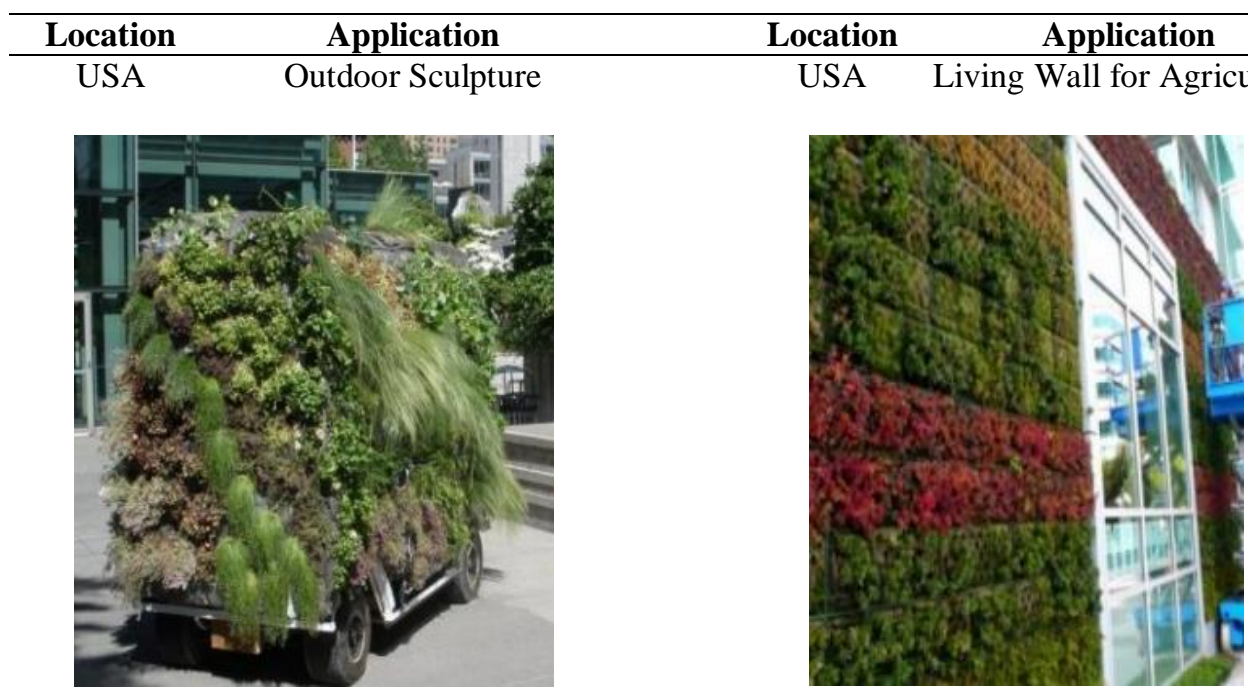

Whole Foods Living Wall for Agriculture planted with edible vegetables

Source: Living Walls: 15 More Vertically Vegetated

Japan Greenery Curtains

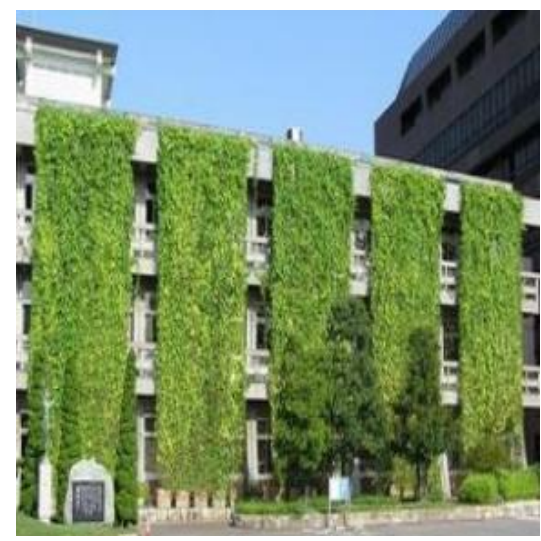

Greenery curtains, Anjo City of Aichi Prefecture

Source: (Japan for Sustainability 2008)
London, Environmental Grafitti Britain

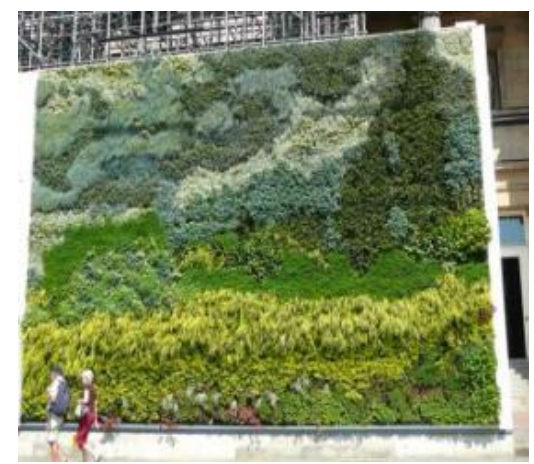

Van-Gogh's "Wheat Field with Cypresses" as a living painting at the National-Gallery Trafalgar Square, London Source: (Collet 2011) 
Table 5. Continue

\begin{tabular}{cccc}
\hline Location & Application & Location & Application \\
\hline Canada & Living Paintings & Changi & Indoor Vertical Garden \\
& & Airport, \\
& Singapore &
\end{tabular}

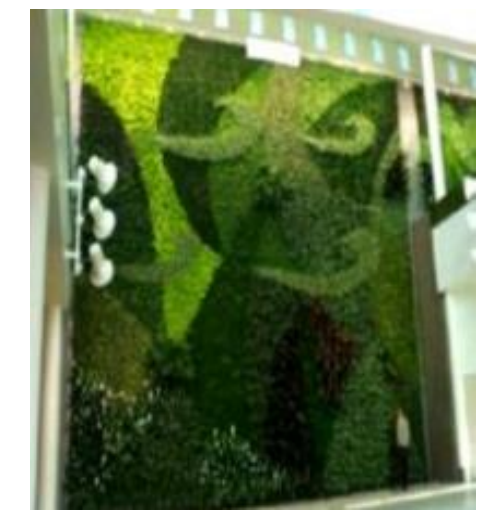

Living Walls at Edmonton International Airport Source: (Poiraud 2012)

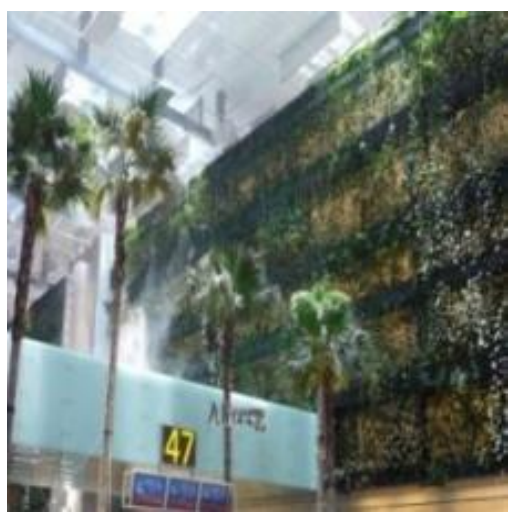

Indoor Vertical Greenery, at Changi Airport, Singapore Source: Living Walls: 15 More Vertically Vegetated Buildings (n.d.)

Note: Various implementation of VG around the world, indoor and outdoor

\section{Vertical Greenery As Public Art}

Rubin (2008) then explains that successful urban greening projects will not only be worthwhile in the long term to the health of the community but essentially rewarding to the participants. Most urban greening endeavours grow out of the passionate pursuit of professional and single-issue advocates with the managerial expertise to execute murals and other public art. Without that kind of deep issue specific experience and uncompromising attention over several years; most of the greening initiatives and projects would never be realized. Urban greening projects can become key components to a successful projects, creating the environment in which more people are comfortable shopping, working or living, and in which they think their community's character is expressed. Public art becomes one of the main ways by which the local history, character and richness of the neighbourhood and its residents are reflected in the new properties.

However, finding practical and effective way to exercise sustainable developments in our cities through public art strategy is yet to be fully explored. In further understanding this issue, Kate Maddison (Chrysalis arts n.d.) from Chrysalis Arts commented that even though artistic considerations are vital in creating public art, art creator could also implement sustainable principles as long as they were supported through the funding and commissioning process. Despite putting upfront people's involvement, collaboration with key partners and promotion of local, public 
artist frequently touched upon environmental considerations but typically fall short of encouraging best practice in promoting low impact and non-polluting methods of implementation. What is required is a particular approach to innovation encompassing environmental, social, economic, management and practical issues and equally applied by both artists and commissioners.

Thus, one way to create a public art that is environmentally sound is through an increase of vertical greenery technologies on the walls of our buildings (Peck \& Kuhn, 1999). By combining aesthetics with environmental principles, vertical gardens are certainly rewriting conventional rules of gardening as more recent green walls are often showing beautiful patterns, it is becoming a new urban art (Séguin, 2012). This idea was well supported by a study conducted by Wong et al. (2010) whereby they have carried out studies on perception of vertical systems Greenery in Singapore to provide aesthetic value as a parameter study. Their findings showed that all respondents were from the developer, consultant, government agencies and the resident agrees to the use of VG to enhance visual appeal. Furthermore, green walls are a good option to consider if space being the constraints, but yet greenery is still needed around the area which definitely adds to the aesthetic value. In an interview with him by Chin Mui Yoon (2010), Blanc talks about this matter, "Over half of the world's population now live in cities; I think it's very important to combine nature with cities instead of separating both from one another,". The walls are works of arts, indeed; and in a concrete jungle, a splash of living green is always refreshing and also beyond aesthetics.

Institute of Landscape Architects Malaysia (ILAM, 2009) in their bulletin has conducted two interviews to further explored VG's potential to be developed in Malaysia, especially in the urban realm. One prominent Landscape Architect, HodsonWalker believes there are great potentials to be developed in Malaysia. According to him, VG's application and design are surely going through a period of refinement and further development, yet with continuing environmental pressure and government policy, green walls will certainly become an important part of modern urban design. Furthermore Mr. Pua, another prominent feature of Malaysian lanscape architectural field also agrees that VG may be built as a work of art for its beauty but in vertical garden design. Yet, we must continue to explore all available options and expand our creativity beyond our imagination. The essential knowledge is within all Landscape Architects, yet the functionality and practicality of these designs have to work hand-in hand with the artistry and creativity of the product, in order to develop effective, beautiful and functional living wall art. Additionally, Patrick Blanc also mention about this potential in his an interview with Patrick Blanc by Chin Mui Yoon (2010) when elaborated that Kuala Lumpur has much potential for Vertical Greenery since out of the identified 8,000 plant species in Malaysia, some 2,500 grow without any soil.

\section{THEORY / RESEARCH METHODS}

In order to further study the potential integration of $\mathrm{VG}$ and public art, this paper studies and reviews 25 selected real life projects in urban Malaysia which include 
Kuala Lumpur, Selangor, Johor and Penang that have applied vertical greenery in their development. Firstly, literature reviews were carried out to obtain information on the projects and their relationship to VG application. Next, out of the 25 projects, six projects were selected to obtain more information through site observation. Last but not least, interview method was also carried out for another four projects. For literature review, information on the projects was obtained from multiple sources such as company brochures, websites and company's collection and this method contributed 15 projects. Site observation method managed to gather six projects while personal interview with the contractors contributed another four projects. This finding shows that different parties were involved and show strong commitment to implement VG in urban Malaysia.

The first dimension of the study was the placement of VG that was then divided into three categories; public, partial public and private. This dimension was chosen in relation to a study by Hunting (2005), whereby he divided PA's placement into the same notion. The second dimension was the name of and various parties involved in the projects. This is important in identifying all the projects that applied VG in their development and parties involved. The third category is the objective of VG application. This aspect is important in order to recognize the objective of VG application, be it aesthetic, economic or environment, and was comparable to Table 3. Next, type and system of VG was also identified. The identification was based on the information obtained from reviews of the literature shown in Table 1 and Figure 1, Figure 2 and Figure 3. Other than that, the location of the vertical greenery also was noted, based on Table 1. Next, the types of public art that the VG fall were also highlighted. This aspect was based on types of public art mentioned in Table 2; integrated, environmental and stands alone. This dimension is the most crucial as it will eventually prove the interrelation of public art and VG. The last measurement is the relationship of that particular VG with public art. The dimension was based on the operational definition of PA used for this paper which is an artistic expression that is positioned in a freely accessed public space for the public to use, but not just any art placed outside yet still carries the basic idea of art which is to enhance spaces. Thus, any VG projects that agree with the operational description will be considered relevant as a public art. Then, the data gained were presented in a table format according to the above dimensions for easy referencing and discussion.

\section{RESULTS AND DISCUSSION}

Table 6 summarizes the findings of the 25 projects derived from the data collected for easy referencing and discussion. In the dimension of $\mathrm{VG}^{\prime}$ 's placement, nine projects placed the VG in a public space whereby the public can directly see and interact with the VG for example, Lot 10 Roof Top, Bukit Bintang (Figure 4). In contrast, four projects fall into the partial public category. Finally, twelve projects positioned the VG at private placement whereas the only people with access to the area can experience the VG for instance Sime Darby Property Head Quarters (Figure 7). This result demonstrated that VG shared the same aspect of public art in terms of its 
placement. VG is not only can be placed but also at an outdoor realm thus giving enormous opportunity for it to be experienced as a public art by the public.

Among all the projects, eleven projects were identified to implement VG for aesthetic value only (Figure 6) whilst another five project used VG for its environmental and aesthetic benefits (Figure 5). Alternatively, only one project was intended to utilize VG as environmental and economic purpose (Figure 8). On the other hand, five projects were recognized to employ VG for all its objectives; aesthetic, environmental and economic. Other than that, 18 projects fall into the category of green wall (Figure 9) while only two projects utilized Vertical Greenery System or Living Wall. However, there are also four developments that utilize Green facade/ Bio-facade wall. Lastly there is only one project used both Green facade and Vertical Greenery System. It was also noted that among the 25 selected real life projects in urban Malaysia studied, twenty of them apply carrier system only (Figure 10) and another four used support system while the remains were identified to combine both carrier and support system.

Referring to the location dimension, 17 VGs were placed outdoors; and another one was located at a semi indoor area. Similarly, only one project located the VG both indoor and outdoor whilst the rest was positioned in an indoor environment. For example, referring to Figure 12, Platinum Sentral which was developed by Malaysian Resources Corporation Bhd. (MRCB) is located in an outdoor space while G Tower's VG is located at both indoor and outdoor (Figure 11 and Figure 13). The analysis of the findings of a relationship of VG with public art, all projects are coherent with the operational definition of public art. Thus, it can be concluded that VG has a strong potential to be implemented as a public art. Referring to the location dimension, 17 VGs were placed outdoors; and another one was located at a semi indoor area (Figure 9). Similarly, only one project located the VG both indoor and outdoor whilst the rest was positioned in an indoor environment. For example, referring to Figure 12, Platinum Sentral is located in an outdoor space while G Tower's VG is located at both indoor and outdoor (Figure 11 and Figure 13).

Based on the types of public art aspect, it was identified that all of the 25 projects falls into the category of environmental art. However, nine of the projects were also categorized as standalone art while the rest of 16 projects fall under integrated art. Last but not least, from the analysis of the findings of a relationship of VG with public art, all projects are consistent with the operational definition of public art. Thus, it can be concluded that VG has a strong potential to be implemented as a public art. 


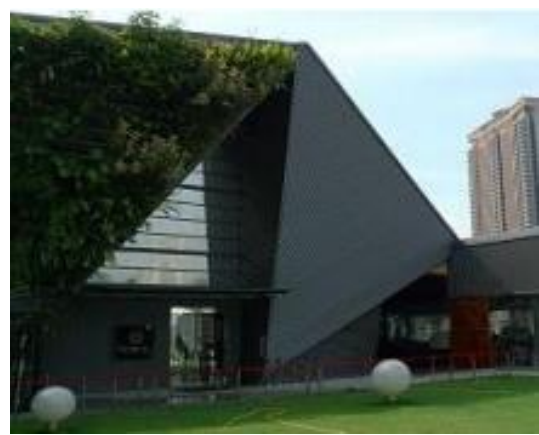

Figure 4. Lot 10 Roof Top, Bukit Bintang

Source: field survey (2013)

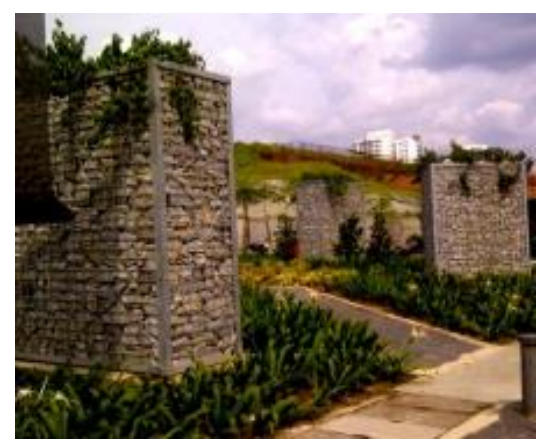

Figure 6. Veo Melawati Sales Gallery green wall Source: field survey (2013)

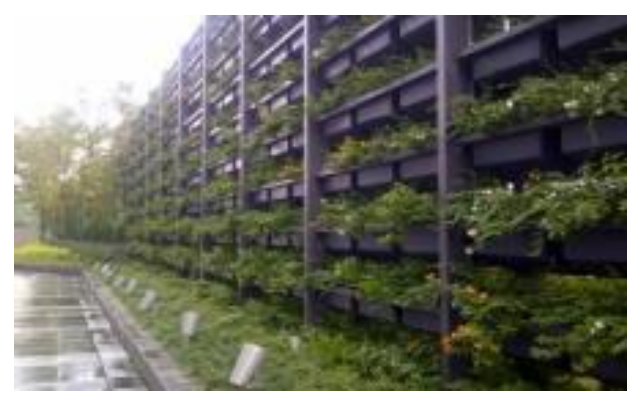

Figure 8. Intermark Integra Tower Source: field survey (2013)

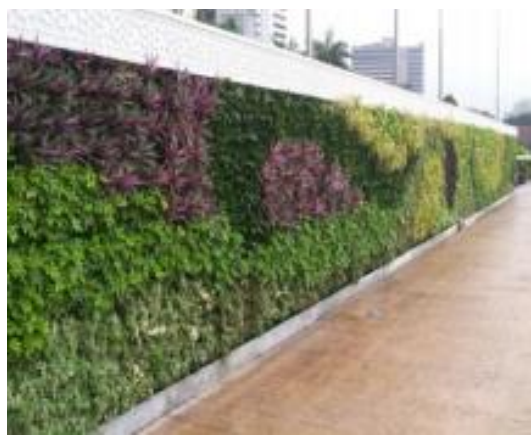

Figure 5. DBKL - KL Heritage Trail Green Wall Source: field survey (2013)

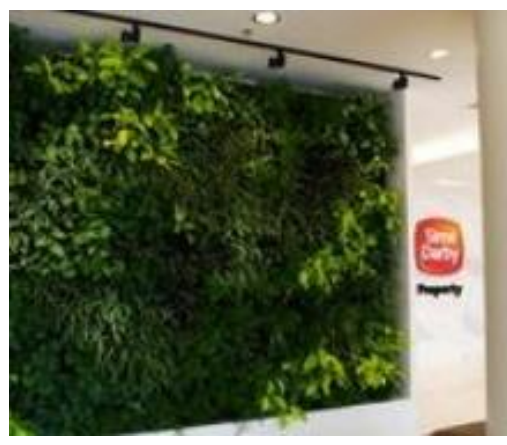

Figure 7. Sime Darby Property Head Quarters Source: : Earthia Green Wall (2013)

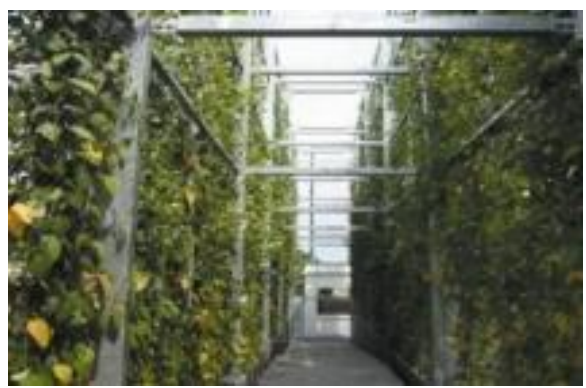

Figure 9. Desa Park City`s Club House Green facade Source: ILAM, (2009) 


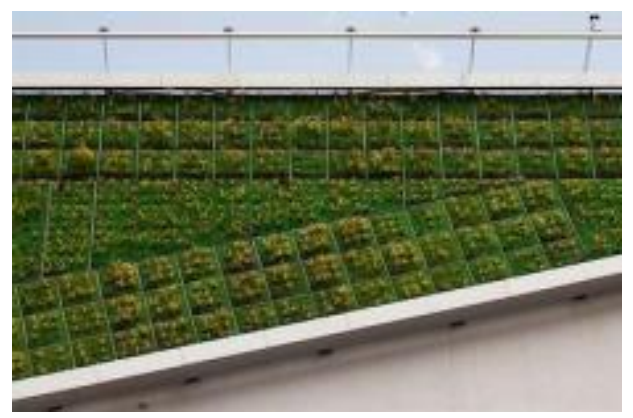

Figure 10. Digi Technology Operation Centre Apply Carrier System Source: field survey (2013)

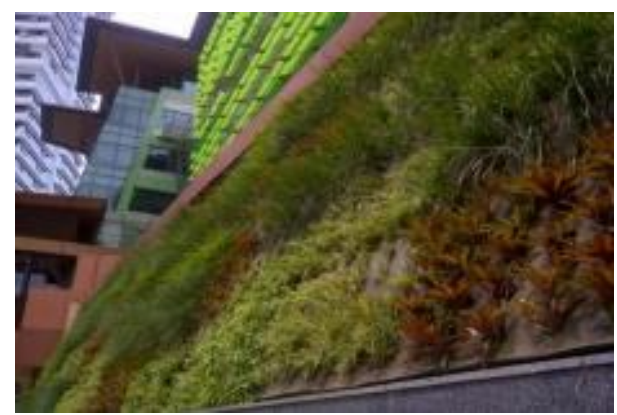

Figure 12. Platinum Central's VG Located at Outdoor Area Source: field survey (2013)

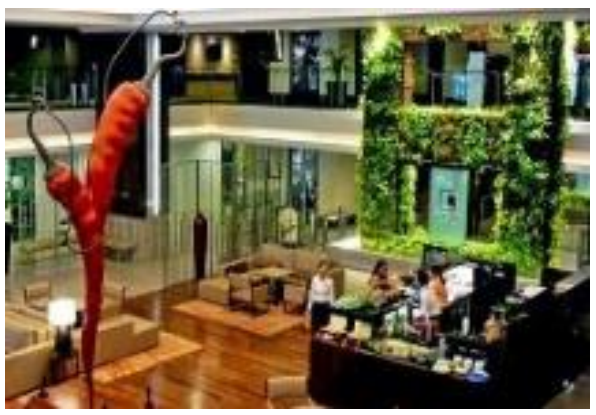

Figure 11. G Tower's VG Located at Indoor Area

Source: field survey (2013)

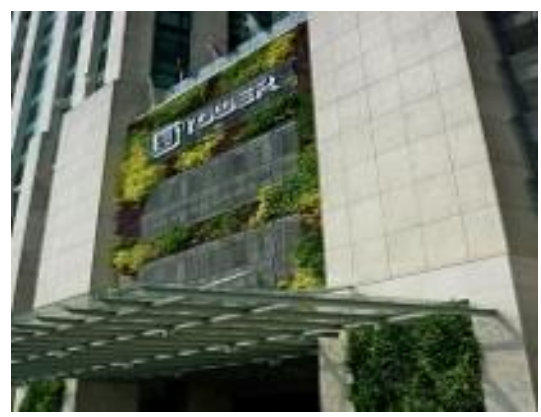

Figure 13. G Tower's SevenStorey Outdoor VG Source: field survey (2013) 
Table 6. Collected Data According to Respective Dimensions for Easy Referencing and Discussion

\begin{tabular}{|c|c|c|c|c|c|c|c|c|}
\hline $\begin{array}{l}\text { VG's } \\
\text { Pla- } \\
\text { cement }\end{array}$ & No & Name, Party Involved & $\begin{array}{c}\text { Objective } \\
\text { of VG Ap- } \\
\text { plication } \\
\end{array}$ & $\begin{array}{l}\text { VG Type \& } \\
\text { System }\end{array}$ & Location & $\begin{array}{l}\text { Data Collection } \\
\text { Method }\end{array}$ & Types of public ar & $\begin{array}{l}\text { Relation } \\
\text { with pu- } \\
\text { blic art }\end{array}$ \\
\hline \multirow{8}{*}{$\begin{array}{c}\text { Public } \\
\text { Place- } \\
\text { ment }\end{array}$} & 1 & $\begin{array}{l}\text { The Sage Community Centre, } \\
\text { Kuala Lumpur (Earthiagreen) }\end{array}$ & - Environment & $\begin{array}{l}\text { - Green Wall } \\
\text { - Carrier }\end{array}$ & $\begin{array}{l}\text { - Semi } \\
\text { Indoor }\end{array}$ & $\begin{array}{l}\text { - Literature re- } \\
\text { view }\end{array}$ & $\begin{array}{l}\text {-Integrated art } \\
\text {-Environmental art }\end{array}$ & $\checkmark$ \\
\hline & 2 & $\begin{array}{l}\text { Platinum Sentral, Kuala Lum- } \\
\text { pur (Malaysian Resources Cor- } \\
\text { poration Bhd.) }\end{array}$ & - Environment & $\begin{array}{l}\text { - Green Wall } \\
\text { - Carrier }\end{array}$ & - Outdoor & $\begin{array}{l}\text { - Literature re- } \\
\text { view } \\
\text { - Site observation }\end{array}$ & $\begin{array}{l}\text { - Integrated art } \\
\text { •Environmental art }\end{array}$ & $\checkmark$ \\
\hline & 3 & $\begin{array}{l}\text { Intermark Integra Tower, Am- } \\
\text { pang, Kuala Lumpur (MGPA } \\
\text { Asia Developments) }\end{array}$ & $\begin{array}{l}\text { - Environment } \\
\text { - Aesthetic } \\
\text { - Economic }\end{array}$ & $\begin{array}{l}\text { - VG System/ } \\
\text { Living Wall } \\
\text { - Planter }\end{array}$ & - Outdoor & $\begin{array}{l}\text { - Literature re- } \\
\text { view }\end{array}$ & $\begin{array}{l}\text { - Stand alone art } \\
\text {-Environmental art }\end{array}$ & $\checkmark$ \\
\hline & 4 & $\begin{array}{l}\text { G Tower, Ampang, Kuala } \\
\text { Lumpur (Earthiagreen) }\end{array}$ & $\begin{array}{l}\text { - Environment } \\
\text { - Aesthetic } \\
\text { - Economic }\end{array}$ & $\begin{array}{l}\text { - Green Wall } \\
\text { - Carrier }\end{array}$ & $\begin{array}{l}\text { - Outdoor } \\
\text { - Indoor }\end{array}$ & $\begin{array}{l}\text { - Literature re- } \\
\text { view } \\
\text { - Site observation }\end{array}$ & $\begin{array}{l}\text { - Integrated art } \\
\text { - Stand alone art } \\
\text { - Environmental art }\end{array}$ & $\checkmark$ \\
\hline & 5 & $\begin{array}{l}\text { Lot } 10 \text { Roof Top, Bukit Bin- } \\
\text { tang, Kuala Lumpur (Sek San } \\
\text { Design) }\end{array}$ & $\begin{array}{l}\text { - Environment } \\
\text { - Aesthetic }\end{array}$ & $\begin{array}{l}\text { - Green Wall } \\
\text { - Carrier }\end{array}$ & - Outdoor & $\begin{array}{l}\text { - Literature re- } \\
\text { view }\end{array}$ & $\begin{array}{l}\text {-Integrated art } \\
\text { •Environmental art }\end{array}$ & $\checkmark$ \\
\hline & 6 & $\begin{array}{l}\text { DBKL - KL Heritage Trail } \\
\text { Green Wall, Kuala Lumpur, } \\
\text { (Lian Shun Technology) }\end{array}$ & $\begin{array}{l}\text { - Environment } \\
\text { - Aesthetic }\end{array}$ & $\begin{array}{l}\text { - Green Wall } \\
\text { - Carrier }\end{array}$ & - Outdoor & $\begin{array}{l}\text { - Literature re- } \\
\text { view } \\
\text { - Site observation }\end{array}$ & $\begin{array}{l}\text {-Integrated art } \\
\text { •Environmental art }\end{array}$ & $\checkmark$ \\
\hline & 7 & $\begin{array}{l}\text { Veo Melawati Sales Gallery, } \\
\text { Selangor (Pembinaan Muzqi } \\
\text { (M) SB) }\end{array}$ & - Aesthetic & $\begin{array}{l}\text { - Green faca- } \\
\text { de } \\
\text { - Planter }\end{array}$ & - Outdoor & $\begin{array}{l}\text { - Site observation } \\
\text { - Interview }\end{array}$ & $\begin{array}{l}\text { - Stand alone art } \\
\text { •Environmental art }\end{array}$ & $\checkmark$ \\
\hline & 8 & $\begin{array}{l}\text { Saujana Resort Entry Green } \\
\text { Wall, Selangor (Artisat SB) }\end{array}$ & - Aesthetic & $\begin{array}{l}\text { - Green Wall } \\
\text { - Carrier }\end{array}$ & - Outdoor & $\begin{array}{l}\text { - Literature re- } \\
\text { view }\end{array}$ & $\begin{array}{l}\text { - Integrated art } \\
\text { •Environmental art }\end{array}$ & $\checkmark$ \\
\hline
\end{tabular}


Table 6. Continue

\begin{tabular}{|c|c|c|c|c|c|c|c|c|}
\hline $\begin{array}{l}\text { VG's } \\
\text { Pla- } \\
\text { cement }\end{array}$ & No & Name, Party Involved & $\begin{array}{l}\text { Objective } \\
\text { of VG Ap- } \\
\text { plication }\end{array}$ & $\begin{array}{l}\text { VG Type \& } \\
\text { System }\end{array}$ & Location & $\begin{array}{l}\text { Data Collection } \\
\text { Method }\end{array}$ & Types of public ar & $\begin{array}{l}\text { Relation } \\
\text { with pu- } \\
\text { blic art }\end{array}$ \\
\hline \multirow{5}{*}{$\begin{array}{l}\text { Partial } \\
\text { Public } \\
\text { Place- } \\
\text { ment }\end{array}$} & 9 & $\begin{array}{l}\text { Qaseh Entry Green Wall, Kinra- } \\
\text { ra, Selangor (Whola SB) }\end{array}$ & - Aesthetic & $\begin{array}{l}\text { - Green faca- } \\
\text { de/Bio- } \\
\text { facade wall }\end{array}$ & - Outdoor & $\begin{array}{l}\text { - Site observation } \\
\text { - Interview }\end{array}$ & $\begin{array}{l}\text {-Integrated art } \\
\text { •Environmental art }\end{array}$ & $\checkmark$ \\
\hline & 10 & $\begin{array}{l}\text { Blu-MED@Mid Valley Mega- } \\
\text { mall, KL (Lian Shun Techno- } \\
\text { logy) }\end{array}$ & $\begin{array}{l}\text { - Aesthetic } \\
\text { - Economic }\end{array}$ & $\begin{array}{l}\text { - Green Wall } \\
\text { - Carrier }\end{array}$ & - Indoor & $\begin{array}{l}\text { - Literature re- } \\
\text { view }\end{array}$ & $\begin{array}{l}\text { - Stand alone art } \\
\text {-Environmental art }\end{array}$ & $\checkmark$ \\
\hline & 11 & $\begin{array}{l}\text { Best Western Hotel Dua Sen- } \\
\text { tral, KL (Eco Outdoor SB) }\end{array}$ & - Aesthetic & $\begin{array}{l}\text { - Green Wall } \\
\text { - Carrier }\end{array}$ & - Outdoor & - Interview & $\begin{array}{l}\text { - Integrated art } \\
\text { - Environmental art }\end{array}$ & $\checkmark$ \\
\hline & 12 & $\begin{array}{l}\text { First Avenue, Bandar Utama, } \\
\text { Petaling Jaya (Hoy Chan SB } \\
\text { Group) }\end{array}$ & $\begin{array}{l}\text { - Environment } \\
\text { - Economic }\end{array}$ & $\begin{array}{l}\text { - Green faca- } \\
\text { de } \\
\text { - } \text { support }\end{array}$ & - Outdoor & $\begin{array}{l}\text { - Literature re- } \\
\text { view } \\
\text { - Site observation }\end{array}$ & $\begin{array}{l}\text {-Integrated art } \\
\text { •Environmental art }\end{array}$ & $\checkmark$ \\
\hline & 13 & $\begin{array}{l}\text { Digi Technology Operation } \\
\text { Centre, Shah Alam, Selangor } \\
\text { (TR Hamzah \& Yeang SB.) }\end{array}$ & - Environment & $\begin{array}{l}\text { - VG System } \\
\text { - Carrier }\end{array}$ & - Outdoor & $\begin{array}{l}\text { - Literature re- } \\
\text { view }\end{array}$ & $\begin{array}{l}\text {-Integrated art } \\
\text { •Environmental art }\end{array}$ & $\checkmark$ \\
\hline \multirow[t]{3}{*}{$\begin{array}{l}\text { Prívate } \\
\text { Place- } \\
\text { ment }\end{array}$} & 14 & $\begin{array}{l}\text { Sime Darby Property Head } \\
\text { Quarters, Ara Damansara, Se- } \\
\text { langor (Earthiagreen) }\end{array}$ & $\begin{array}{l}\text { - Environment } \\
\text { - Aesthetic } \\
\text { - Economic }\end{array}$ & $\begin{array}{l}\text { - Green Wall } \\
\text { - Carrier }\end{array}$ & - Indoor & $\begin{array}{l}\text { - Literature re- } \\
\text { view }\end{array}$ & $\begin{array}{l}\text {-Integrated art } \\
\text { •Environmental art }\end{array}$ & $\checkmark$ \\
\hline & 15 & $\begin{array}{l}\text { Pavillion Executive Office, } \\
\text { Kuala Lumpur (Earthiagreen) }\end{array}$ & $\begin{array}{l}\text { - Environment } \\
\text { - Aesthetic }\end{array}$ & $\begin{array}{l}\text { - Green Wall } \\
\text { - Carrier }\end{array}$ & - Indoor & $\begin{array}{l}\text { - Literature re- } \\
\text { view }\end{array}$ & $\begin{array}{l}\text {-Integrated art } \\
\text {-Environmental art }\end{array}$ & $\checkmark$ \\
\hline & 16 & $\begin{array}{l}\text { Private residence, Jalan Pudina, } \\
\text { Bangsar, KL (Artisat SB) }\end{array}$ & - Aesthetic & $\begin{array}{l}\text { - Green Wall } \\
\text { - Carrier }\end{array}$ & - Indoor & $\begin{array}{l}\text { - Literature re- } \\
\text { view }\end{array}$ & $\begin{array}{l}\text {-Integrated art } \\
\text {-Environmental art }\end{array}$ & $\checkmark$ \\
\hline
\end{tabular}


Table 6. Continue

\begin{tabular}{|c|c|c|c|c|c|c|c|c|}
\hline $\begin{array}{l}\text { VG's } \\
\text { Pla- } \\
\text { cement }\end{array}$ & No & Name, Party Involved & $\begin{array}{l}\text { Objective } \\
\text { of VG Ap- } \\
\text { plication } \\
\end{array}$ & $\begin{array}{l}\text { VG Type \& } \\
\text { System }\end{array}$ & Location & $\begin{array}{l}\text { Data Collection } \\
\text { Method }\end{array}$ & Types of public ar & $\begin{array}{l}\text { Relation } \\
\text { with pu- } \\
\text { blic art }\end{array}$ \\
\hline & 17 & $\begin{array}{l}\text { Private residence, Damansara } \\
\text { Heights, Kuala Lumpur (Artisat } \\
\text { SB) }\end{array}$ & - Aesthetic & $\begin{array}{l}\text { - Green Wall } \\
\text { - Carrier }\end{array}$ & - Indoor & $\begin{array}{l}\text { - Literature re- } \\
\text { view }\end{array}$ & $\begin{array}{l}\text { - Integrated art } \\
\text { - Environmental art }\end{array}$ & $\checkmark$ \\
\hline & 18 & $\begin{array}{l}\text { Desa Park City's Club House, } \\
\text { Kuala Lumpur (Earthiagreen) }\end{array}$ & - Aesthetic & $\begin{array}{l}\text { - Green faca- } \\
\text { de/Bio- } \\
\text { facade wall } \\
\text { - Support }\end{array}$ & - Outdoor & $\begin{array}{l}\text { - Literature re- } \\
\text { view }\end{array}$ & $\begin{array}{l}\text { - Stand alone art } \\
\text {-Environmental art }\end{array}$ & $\checkmark$ \\
\hline & 19 & $\begin{array}{l}\text { Subang Olive Residences, } \\
\text { Subang, Selangor (Eurodeck } \\
\text { SB) }\end{array}$ & - Aesthetic & $\begin{array}{l}\text { - Green faca- } \\
\text { de/VG Sys- } \\
\text { tem } \\
\text { - Planter \& } \\
\text { Carrier }\end{array}$ & - Outdoor & - Interview & $\begin{array}{l}\text { - Stand alone art } \\
\text {-Environmental art }\end{array}$ & $\checkmark$ \\
\hline & 20 & $\begin{array}{l}\text { Dataran Prima, Petaling Jaya, } \\
\text { Selangor (1Eco Innovation SB.) }\end{array}$ & $\begin{array}{l}\text { - Environment } \\
\text { - Aesthetic }\end{array}$ & $\begin{array}{l}\text { - Green Wall } \\
\text { - Carrier }\end{array}$ & - Outdoor & - Interview & $\begin{array}{l}\text {-Stand alone art } \\
\text {-Environmental art }\end{array}$ & $\checkmark$ \\
\hline & 21 & $\begin{array}{l}\text { Setia Eco Gardens, Johor SP } \\
\text { Setia Bhd. Group }\end{array}$ & $\begin{array}{l}\text { - Environment } \\
\text { - Aesthetic } \\
\text { - Economic }\end{array}$ & $\begin{array}{l}\text { - Green Wall } \\
\text { - Carrier }\end{array}$ & - Outdoor & $\begin{array}{l}\text { - Literature re- } \\
\text { view }\end{array}$ & $\begin{array}{l}\text { - Stand alone art } \\
\text {-Environmental art }\end{array}$ & $\checkmark$ \\
\hline & 22 & $\begin{array}{l}\text { G Hotel, Penang (LandArt Sdn. } \\
\text { Bhd.) }\end{array}$ & $\begin{array}{l}\text { - Environment } \\
\text { - Aesthetic } \\
\text { - Economic }\end{array}$ & $\begin{array}{l}\text { - Green Wall } \\
\text { - Planter }\end{array}$ & - Outdoor & $\begin{array}{l}\text { - Literature re- } \\
\text { view }\end{array}$ & $\begin{array}{l}\text { - Stand alone art } \\
\text {-Environmental art }\end{array}$ & $\checkmark$ \\
\hline & 23 & $\begin{array}{l}\text { Mr. Yong's Residence, Penang } \\
\text { (LandArt Sdn. Bhd.) }\end{array}$ & - Aesthetic & $\begin{array}{l}\text { - Green Wall } \\
\text { - Planter }\end{array}$ & - Outdoor & $\begin{array}{l}\text { - Literature re- } \\
\text { view }\end{array}$ & $\begin{array}{l}\text {-Stand alone art } \\
\text {-Environmental art }\end{array}$ & $\checkmark$ \\
\hline
\end{tabular}


Table 6. Continue

\begin{tabular}{|c|c|c|c|c|c|c|c|c|}
\hline $\begin{array}{l}\text { VG's } \\
\text { Pla- } \\
\text { cement }\end{array}$ & No & Name, Party Involved & $\begin{array}{l}\text { Objective } \\
\text { of VG Ap- } \\
\text { plication }\end{array}$ & $\begin{array}{l}\text { VG Type \& } \\
\text { System }\end{array}$ & Location & $\begin{array}{l}\text { Data Collection } \\
\text { Method }\end{array}$ & Types of public ar & $\begin{array}{l}\text { Relation } \\
\text { with pu- } \\
\text { blic art } \\
\end{array}$ \\
\hline & 24 & $\begin{array}{l}11 \text { @ Mont Kiara, Kuala Lum- } \\
\text { pur (Earthiagreen) }\end{array}$ & - Aesthetic & $\begin{array}{l}\text { - Green Wall } \\
\text { - Carrier }\end{array}$ & - Outdoor & $\begin{array}{l}\text { - Literature re- } \\
\text { view }\end{array}$ & $\begin{array}{l}\text {-Integrated art } \\
\text { • Environmental art }\end{array}$ & $\checkmark$ \\
\hline & 25 & $\begin{array}{l}\text { Private residence, Sri Hartamas, } \\
\text { Kuala Lumpur }\end{array}$ & - Aesthetic & $\begin{array}{l}\text { - Green Wall } \\
\text { - Carrier }\end{array}$ & - Indoor & $\begin{array}{l}\text { - Literature re- } \\
\text { view }\end{array}$ & $\begin{array}{l}\text {-Integrated art } \\
\text { - Environmental art }\end{array}$ & $\checkmark$ \\
\hline
\end{tabular}

Note: Results shown great potential for VG to be implemented as public art 


\section{CONCLUSIONS}

In summary, both public art and VG can contribute to the quality of life as they complement each other in terms of its aesthetic, environmental and economic quality. This study has found the combination of both will not only create a public art that is high in aesthetic quality but also environmentally sound. This paper has also proven that VG has a strong potential to be implemented as public art and it may be built as a work of art for its beauty. Nevertheless, we must continue to explore all available options and expand our creativity beyond our imagination. The basic knowledge is within people that are involved in the built environment, yet the functionality and practicality of these designs have to work hand-in hand with the artistry and creativity of the product, in order to create a beautiful and functional living wall art. Hence, more attention should be given on developing creative, innovative and quality environment that will eventually encourage further research on integrating VG as public art in the urban landscape. Therefore, it is hoped that this exploratory study will be useful in upgrading the functions, ideas and strategies in approaching VG and public art and will also be the launch pad for the public art to go much further, especially in Malaysian urban landscapes.

\section{REFERENCES}

----------, Living Walls: 15 More Vertically Vegetated Buildings, <http://webecoist.momtastic.com> (Accessed on 28 March 2013).

- (2013), Vertical gardens a green solution for urban setting, Times of India, $<$ http://articles.timesofindia.indiatimes.com/2013-02-14/pune/37099689_-

1_vertical-gardens-private-garden-conventional-garden> (Accessed March $25,2013)$.

Afrin, S. (2009), Green Skyscraper: Integration of Plants into Skyscrapers Green Skyscraper: Integration of Plants into Skyscrapers, Kungliga Tekniska högskolan.

Baskaran, B. (2003), Evaluating Rooftop and Vertical Gardens as an Adaptation Strategy for Urban Areas Brad Bass; Ottawa, <http://lib.fo.am/_media/rooftop_and_vertical_gardens_as_adaption_strategy_for_urban_areas.pdf $>$.

Blanc, P. (2008), The Vertical Garden: From Nature to the City, W.W. Norton \& Company, Inc, New York.

Blanc, P., Pont Max Juvenal, Aix en Provence Vertical Garden Patrick Blanc, $<$ http://www.verticalgardenpatrickblanc.com> (Accessed on 28 March 2013).

Bostwick, E. A. (2008), Going Green with Public Art: Considering Environmental Standards in Public Art Policies, University of Oregon, <https://scholarsbank.uoregon.edu>.

Chrysalis Arts, Public Art Sustainability Assessment.

Collet, M. (2011), Van Gogh Painting Recreated as an Amazing Living Wall, $<$ http://www.environmentalgraffiti.com/.> (Accessed on 28 March 2013).

Dunnett, N. (2008), Planting Green Roofs and Living Walls, Rev. and updated ed., (2nd ed.), Or.Timber Press, Portland. 
Earthia Green Wall (2013), Briefing Presentation, <www.earthiagreen.com> (Acessed on 18 March 2013).

Grant, D., (2012), Sustainability Has Become a Growing Focus of Artists ' (and Art Schools') Attention, Huffipost Art \& Culture, <http://www.huffingtonpost.com> (Accessed on 17 October 2012).

Green Roofs (2008), Introduction to Green Walls Technology, Benefits \& Design, <http://www.greenscreen.com>.

G TOWER-Rebuilding the Green Concept (2012), G TOWER-Rebuilding the green concept, The Star, <http://thestar.com.my>.

Hunting, D. (2005), Public Art Policy: Examining an Emerging Discipline, 2(1), 17, <www.asu.edu>, (Acessed on 18 March 2013).

Hart, K. (2001), Living Walls, <www.GreenHomeBuilding.com> (Accessed on 18 March 2013).

Institute of Landscape Architects Malaysia (ILAM) (2009), Landskap Bulletin No 4, p.20, Institute of Landscape Architects Malaysia (ILAM).

Irons, K. (2012), The Purpose \& Value of Public Art, eHOW, <http://www.ehow.com> (Accessed on 24 September 2012).

Jaafar, B. and Said, I. (2011), Evaluating the Impact of Vertical Greenery System on Cooling Effect on High Rise Buildings and Surroundings: A Review, In Skudai, Johor, Malaysia: Senvar 12 2011. Available at: www.epublication.fab.utm.my/180/1/SENVAR1201.pdf.

Japan for Sustainability (2008), Green the City with "Greenery Curtains” Japan for Sustainability, <http://www.japanfs.org> (Accessed on 28 March 2013).

Meinhold, B. (2009), North America's Largest Living Wall Installation by PNC Inhabitat - Sustainable Design Innovation, Eco Architecture, Green Building. Inhabitat, <http://inhabitat.com> (Accessed on 26 March 2013).

Mohd Fabian, H., Osman, M.T. and Mohd Nasir, B. (2012), Towards Integrating Public Art in Malaysian Urban Landscape, Pertanika J. Soc. Sci. \& Hum, 20(2), 251-263, <http://www.pertanika.upm.edu.my>.

Mustafa, M. (2009), Public Art in the Federal Territory of Putrajaya: Questions of Value and Role, Journal of Arts Discourse, 8, 69-96. <http://wacanaseni.usm.my>.

Wong, N. H., Tan, A. Y. K., Chen, Y., Sekar, K., Tan, P. Y., Chan, D., Kelly Chiang, N.C.W. (2010), ScienceDirect Ad, Building and Environment Issue, 45(3), 663-672, <http://linkinghub.elsevier.com>.

Peck, S. W. and Kuhn, M. E. (1999), Greenbacks from Green Roofs: Forging A New Industry in Canada Status Report on Benefits, Barriers and Opportunities for Green Roof and Vertical Garden.

Poiraud, P. (2012), Gigantic living paintings unveiled at Edmonton International Airport, <http://finance.yahoo.com>.

Rochelle (2010), Vertical Gardening Inspiration \& DIY, <http://www.studiogblog.com> (Accessed on 24 February 2013).

Sage Vertical Gardens. (2013), Botanic Sculpture Sage Vertical Gardens, Sage Vertical Garden Systems LLC US and International Patents Pending, $<$ http://www.sageverticalgardens.com> (Accessed on 23 March 2013).

Séguin, M. L. (2012), Green Walls. Architecture Posts, <http://landarchs.com>. 
Shunmugam, V. (2010), By the artists, for the people, The Star, <http://thestar.com.my>.

Sia, A. (2011), Growing Gardens In The Skies, p.1975.

The Hamilton Public Art Master Plan (2009), The Hamilton Public Art Master Plan, Hamilton, Ontario, <http://www.hamilton.ca>.

Transport, S. (2012), Greening, 01, 1-28.

TwistedSifter (2011), 15 Incredible Vertical Gardens Around the World, <http://twistedsifter.com> (Accessed on 2 March 2013).

Urban Landscape Inc. (2012), Living Walls - The Art of Vertical Landscape - Urban Landscape Design Urban Landscape Design \& Landscape Construction California, Urban Landscape Inc., <http://urbanlandscape.com> (Accessed on 14 March 2013).

Vertical Gardens (2009), Vertical Gardens, <http://www.exitart.org/sea> (Accessed on 20 February 2013).

Watts, P. (2009), Report from Seattle Public Art Conference, Ecoartspaceblog. $<$ http://ecoartspace.blogspot.com> (Accessed on 23 March 2013).

Yoon, C. M. (2010), Wrapped in life-giving green, The Star online, <http://thestar.com.my> (Accessed on 15 June 2013). 
Bakar, Mansor, Harun: APPROACHING VERTICAL GREENERY AS PUBLIC ART: A REVIEW ON

This page intentionally left blank 